\title{
Low-level laser irradiation effect on endothelial cells under conditions of hyperglycemia
}

\author{
Krzysztof Góralczyk $^{1}$ - Justyna Szymańska ${ }^{2}$ Katarzyna Szot ${ }^{1}$ - Jacek Fisz ${ }^{2}$. \\ Danuta Rość ${ }^{1}$
}

Received: 3 November 2015 / Accepted: 14 January 2016 / Published online: 9 February 2016

(C) The Author(s) 2016. This article is published with open access at Springerlink.com

\begin{abstract}
Diabetes mellitus is considered to be a very serious lifestyle disease leading to cardiovascular complications and impaired wound healing observed in the diabetic foot syndrome. Chronic hyperglycemia is the source of the endothelial activation. The inflammatory process in diabetes is associated with the secretion of inflammatory cytokines by endothelial cells, e.g., tumor necrosis factor-alpha (TNF- $\alpha$ ) and interleukin 6 (IL-6). The method of phototherapy using laser beam of low power (LLLT - low-level laser therapy) effectively supports the conventional treatment of diabetic vascular complications such as diabetic foot syndrome. The aim of our study was to evaluate the effect of low-power laser irradiation at two wavelengths ( 635 and $830 \mathrm{~nm}$ ) on the secretion of inflammatory factors (TNF- $\alpha$ and IL-6) by the endothelial cell culture-HUVEC line (human umbilical vein endothelial cell) - under conditions of hyperglycemia. It is considered that adverse effects of hyperglycemia on vascular endothelial cells may be corrected by the action of LLLT, especially with the wavelength of $830 \mathrm{~nm}$. It leads to the reduction of TNF- $\alpha$ concentration in the supernatant and enhancement of cell proliferation. Endothelial cells play an important role in the pathogenesis of diabetes; however, a small number of studies evaluate an impact of LLLT on these cells under conditions of hyperglycemia. Further work on this subject is warranted.
\end{abstract}

Krzysztof Góralczyk

krzyg@cm.umk.pl

1 Department of Pathophysiology, Faculty of Pharmacy, Nicolaus Copernicus University in Toruń, Collegium Medicum in Bydgoszcz, Skłodowskiej-Curie Street No 9, Bydgoszcz, Poland

2 Department of Laserotherapy and Physiotherapy, Faculty of Health Sciences, Nicolaus Copernicus University in Torun, Collegium Medicum in Bydgoszcz, Bydgoszcz, Poland
Keywords Low-level laser therapy · TNF-alpha · IL-6 . Endothelial cells

\section{Introduction}

In the twenty-first century, diabetes mellitus has become an epidemic and being a risk factor of cardiovascular diseases [1] leads to an increased mortality in the population of developed and developing countries. Its severe complication-diabetic foot syndrome - is the primary cause of limb amputation due to vascular complications. An impaired wound healing is crucial in the clinical manifestation of diabetes, and hyperglycemia in uncontrolled diabetes is the major pathogenic factor.

The process of wound repair involves several consecutive phases (inflammatory and proliferative phase, remodeling of the wound), and it demands various factors: polypeptide growth factors, cytokines, and extracellular matrix components $[2,3]$. Many of them are derived from endothelial cells, namely vascular endothelial growth factor (VEGF), tissue plasminogen activator (t-PA), metalloproteinases (MMP-2, MMP-9) and their inhibitors, tumor necrosis factor alpha (TNF- $\alpha$ ), and interleukin-6 (IL-6). Therefore, the endothelium is essential in the maintenance of vascular homeostasis [4]. Hyperglycemia in diabetes is responsible for damaging of the endothelium and increases inflammation on the surface of the vascular lining [5].

TNF- $\alpha$ enhances the inflammation process and has an impact on angiogenesis and destructive processes. It induces the production of other pro-inflammatory cytokines, e.g., IL-6. It contributes to oxidative stress by generating reactive oxygen species (ROS) [6]. TNF- $\alpha$ is the most important proinflammatory factor in diabetes. 
IL-6 is a pleiotropic cytokine with a wide spectrum of biological activity. Its main function is to participate in the immune response and acute phase of inflammatory reaction where it acts together with TNF- $\alpha$ [7]. In the acute inflammatory response, Il- 6 has regulatory properties and limits the production of pro-inflammatory cytokines such as TNF- $\alpha$ [8]. IL-6 can therefore suppress the development of diabetes. However, when produced in excess and in long term, it promotes a passage of inflammation into chronic phase and contributes to the development of many diseases [9].

Many studies have shown that high glucose concentration $(20-40 \mathrm{mM} / \mathrm{L})$ in the culture medium imitates conditions as in uncontrolled diabetes and adversely affects cell proliferation leading to cell damage and apoptosis [10-12].

The number of patients suffering from diabetes is still increasing, and chronic complications of microangiopathy and macroangiopathy cause disability and inability to work and a deterioration of the quality of life. Diabetes is also the leading cause of amputation [13] due to non-healing wounds. The method of phototherapy using laser beam of low power (LLLT - low-level laser therapy) effectively supports conventional treatment and brings a significant improvement in the quality of life in diabetes.

According to Brosseau et al. [14], lasers have been used in medicine since at least 1974 when LLLT was officially implemented in the USSR as an alternative non-invasive treatment of rheumatoid arthritis. A number of studies have reported the positive impact of LLLT on alleviation symptoms caused by hyperglycemic conditions. These investigations involved humans and animals and were conducted in vitro [15-17] and in vivo [18-20]. Mainly, they evaluated fibroblasts and osteoblasts. Research from the last decade provides data on the key role of the vascular endothelium in maintaining vascular homeostasis and pathogenesis of vascular diseases. Endothelial cells line the walls of blood vessels and therefore are on the front line of contact with the high concentration of glucose.

The aim of our study was to evaluate the effect of lowpower laser irradiation at two wavelengths (635 and $830 \mathrm{~nm}$ ) on the secretion of inflammatory factors (TNF- $\alpha$ and IL-6) by the endothelial cell culture-HUVEC line (human umbilical vein endothelial cells) - under conditions of hyperglycemia.

\section{Material and methods}

Endothelial cells (HUVEC line) were derived from human umbilical veins by the enzyme method using collagenase according to the method described by Jaffe et al. [21]. Cells were cultured in M199 media supplemented with $20 \%$ fetal bovine serum (FBS), $100 \mathrm{U} / \mathrm{ml}$ penicillin (Gibco ${ }^{\circledR}$ products), and growth factors $50 \mu \mathrm{g} / \mathrm{ml}$ endothelial cell growth supplement
(ECGS - Corning Inc. USA) and heparin. ECGS was obtained from a bovine neural tissue. The cells were incubated at $37{ }^{\circ} \mathrm{C}$ in a humidified atmosphere with $5 \% \mathrm{CO}_{2}$. After $2-4$ passages and seeding the cells in 6-well culture plates, the proper experiment was conducted. HUVECs were placed at a density of $7.5 \times 10^{4}$ cells per square centimeter.

With the exception of the control group, $30 \mathrm{mM} / \mathrm{L}$ glucose was added to the culture medium. The culture medium was changed every 3 days. The experiment was repeated three times with three independent cells isolations.

A semiconductor-based laser (Roithner Lasertechnik $\mathrm{GmbH}$, Austria) was used to generate a visible laser beam with the wavelength of $635 \mathrm{~nm}$ (AlGaAlP) and the wavelength of $830 \mathrm{~nm}$ (GaAlAs) in the infrared. The authors have used the optoelectronic set for controlled, reproducible exposure of electromagnetic irradiation of biological structures in the spectral band of tissue transmission window $600-1000 \mathrm{~nm}$ [22]. The power of laser sources was $30 \mathrm{~mW}$ for $635 \mathrm{~nm}$ and $60 \mathrm{~mW}$ for $830 \mathrm{~nm}$. The power density at the cell-layer level measured by using a laser power meter (Gentec, Model SOLO2 R2, Canada) was $1.875 \mathrm{~mW} / \mathrm{cm}^{2}$ for $635 \mathrm{~nm}$ and $3.75 \mathrm{~mW} / \mathrm{cm}^{2}$ for $830 \mathrm{~nm}$. The power was constant in all experiments. The distance between the laser source and the surface of application was $10 \mathrm{~cm}$, the application was carried through an optical fiber, and there was $80 \mathrm{~cm}^{2}$ of irradiated area. The experiment was conducted in four groups: $1-$ no glucose in culture medium, no irradiation (control group); 2 glucose, no irradiation; 3-glucose, laser irradiation with wavelength of $635 \mathrm{~nm}$, energy dose of $2 \mathrm{~J} / \mathrm{cm}^{2}$; and $4-\mathrm{glu}$ cose, laser irradiation with wavelength of $830 \mathrm{~nm}$, energy dose of $2 \mathrm{~J} / \mathrm{cm}^{2}$. The time of laser irradiation was $1066 \mathrm{~s}$ for $635 \mathrm{~nm}$ and $533 \mathrm{~s}$ for $830 \mathrm{~nm}$. The cells were cultured for 7 days, with two irradiations on days 5 and 6 . At the end of experiment, conditioned medium from each well of culture plates was collected and centrifuged for $10 \mathrm{~min}$ at $2000 \times g$ and frozen at $-86^{\circ} \mathrm{C}$. After thawing, the concentration of TNF- $\alpha$ and IL- 6 in the supernatant was measured by ELISA test (eBioscience, Vienna, Austria) according to the manufacturer's instructions. The remaining cells on the bottom of each well were harvested by using trypsin and counted by Buerker hemocytometry. This method uses trypan blue dye according to the method described by Basso et al. [23]. The results of the concentration of the parameters in the supernatant from each well of culture plates were analyzed per number of cells in each well.

Statistical analysis was performed using Statistica 10.0 (StatSoft Inc.). The one-way ANOVA was used for parametrical analysis (proliferation), and Kruskal-Wallis test was used for nonparametrical comparisons (TNF- $\alpha$ and IL-6). Statistical significance was defined as $P<0.05$. The results were presented as mean $(\mathrm{M}) \pm$ standard deviation $(\mathrm{SD})$ or median $(\mathrm{Me})$, lower $\left(\mathrm{Q}_{1}\right)$ and upper $\left(\mathrm{Q}_{3}\right)$ quartile. 
The approval of the Bioethics Commission of the NCU Collegium Medicum in Bydgoszcz was obtained, No KB/ 135/2009, date: 27 May 2014.

\section{Results}

Figure 1 shows the results concerning the effect of low-level laser therapy on TNF- $\alpha$ concentration in the supernatant from HUVEC culture which was grown in the high concentration of glucose in the culture medium (glucose concentration of $30 \mathrm{mM} / \mathrm{L}$ ). The level of TNF- $\alpha$ in the control group (group 1) without glucose in the medium and without laser irradiation was $0.79 \mathrm{pg} / 10^{5}$ cells. Its concentration was only slightly higher $\left(0.85 \mathrm{pg} / 10^{5}\right.$ cells $)$ in the unirradiated group 2 containing glucose in the medium. The cells from groups 3 and 4 were grown in medium with glucose and irradiated at the wavelength of 635 and $830 \mathrm{~nm}$, respectively. The TNF- $\alpha$ level in group 3 was slightly lower and in group 4 notably lower when compared to the group 2 result. The concentration in group 4 was $0.55 \mathrm{pg} / 10^{5}$ cells and was about $35 \%$ lower than in group 2. However, the final outcome of the ANOVA testing was statistically non-significant and reported as 0.1033 .

Figure 2 presents the concentration of interleukin 6 in the corresponding groups as in Fig. 1. The concentration of IL-6 increased several times after the addition of glucose to the culture medium. There was a statistically significant difference between the three experimental groups $(2,3,4)$ and the control group $(P=0.0003, P=0.0013, P=0.0219$, respectively). No effect of the laser was observed. There was no increase of IL-6 concentration in groups 3 and 4 when compared to group 2. Difference between groups 2, 3, and 4 was statistically non-significant.

Figure 3 shows the number of HUVECs which was the highest in the control group, while the lowest number was observed in group 2. This difference in relation to the control group was statistically significant $(P=0.0207)$. The number of cells in group 3 was slightly higher compared to group 2 and in group 4 reached the level similar to the control group.

\section{Discussion}

High concentration of glucose present in diabetes causes damage to endothelial cells. It is accompanied by inflammation associated with the secretion of pro-inflammatory cytokines such as TNF- $\alpha$ and IL- 6 . An increased secretion of TNF- $\alpha$ and IL- 6 under conditions of hyperglycemia is a finding observed by several authors [24-27]. It is accompanied by a reduction of cell proliferation $[10,11,15]$. However, in the study of Brandner et al. [28], level of TNF- $\alpha$ in cultured diabetic keratinocytes did not differ significantly from nondiabetic keratinocytes, although the level of TNF- $\alpha$ messenger RNA (mRNA) in the skin of patients with diabetes was significantly higher compared to those without diabetes. The authors explain this finding by the fact that keratinocytes are not a major producer of TNF- $\alpha$ in the skin. In our study, TNF- $\alpha$ was only slightly higher in cell cultures with the high glucose level in the medium compared to cells grown under normal conditions (Fig. 1). In contrast, the IL-6 level was significantly increased in the groups with glucose in the medium compared to the control group without glucose $(P=0.0003$; Fig. 2$)$. IL-6 can inhibit the production of TNF- $\alpha[8,29]$ which is why a considerable increase of IL- 6 under hyperglycemic conditions might have an impact on the level of TNF- $\alpha$. Other authors have also observed the significant increase of IL- 6 concentration under conditions of elevated glucose level [24, 30, 31]. In our study, a much smaller number of endothelial cells cultured under hyperglycemic conditions compared to culture under normal conditions $(P=0.0207$, Fig. 3$)$ shows the negative
Fig. 1 The concentration of tumor necrosis factor-alpha (TNF$\alpha$ ) in the supernatant of HUVEC cells culture depending on hyperglycemia and laser irradiation of different wavelengths. $G$ glucose in culture medium, $L(635)$ laser irradiation with wavelength of $635 \mathrm{~nm}$, $L(830)$ laser irradiation with wavelength of $830 \mathrm{~nm}$. $P$ value of ANOVA was 0.1033

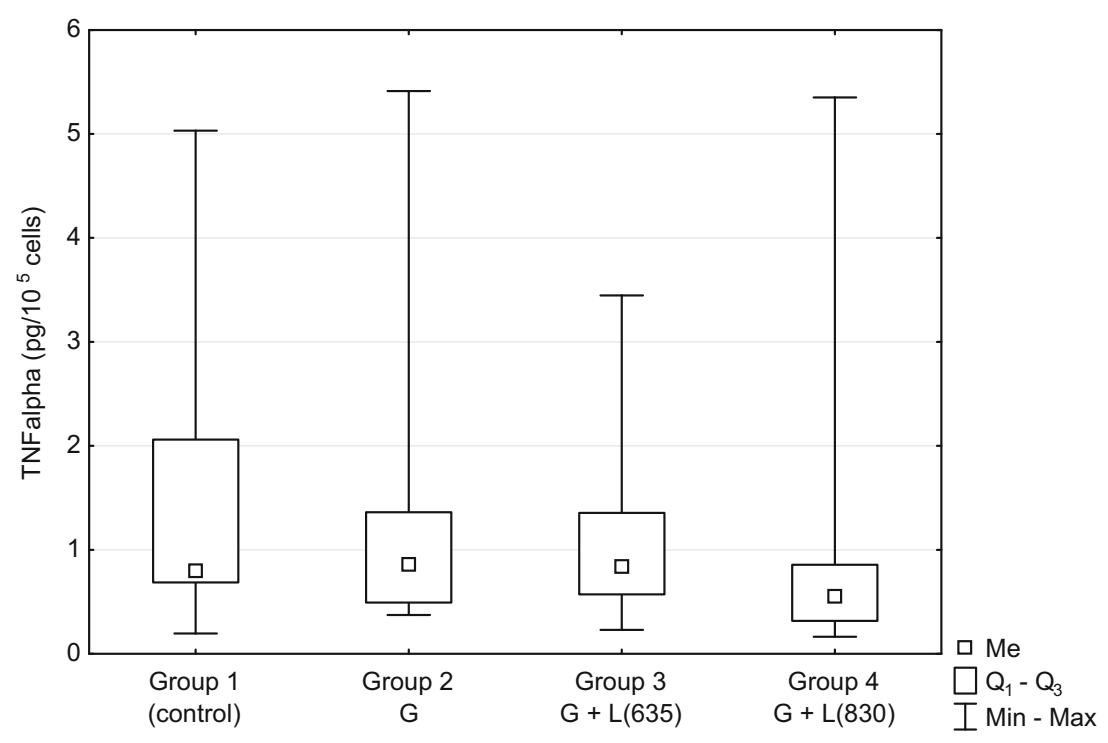


Fig. 2 The concentration of Interleukin-6 (IL-O) in the supernatant of HUVEC cells culture depending on hyperglycemia and laser irradiation of different wavelengths. $G$ glucose in culture medium, $L(635)$ laser irradiation with wavelength of $635 \mathrm{~nm}$, L(830) laser irradiation with wavelength of $830 \mathrm{~nm}$. There was a statistically significant difference between the three experimental groups $(2,3,4)$ and the control group $(P=0.0003$, $P=0.0013, P=0.0219$, respectively)

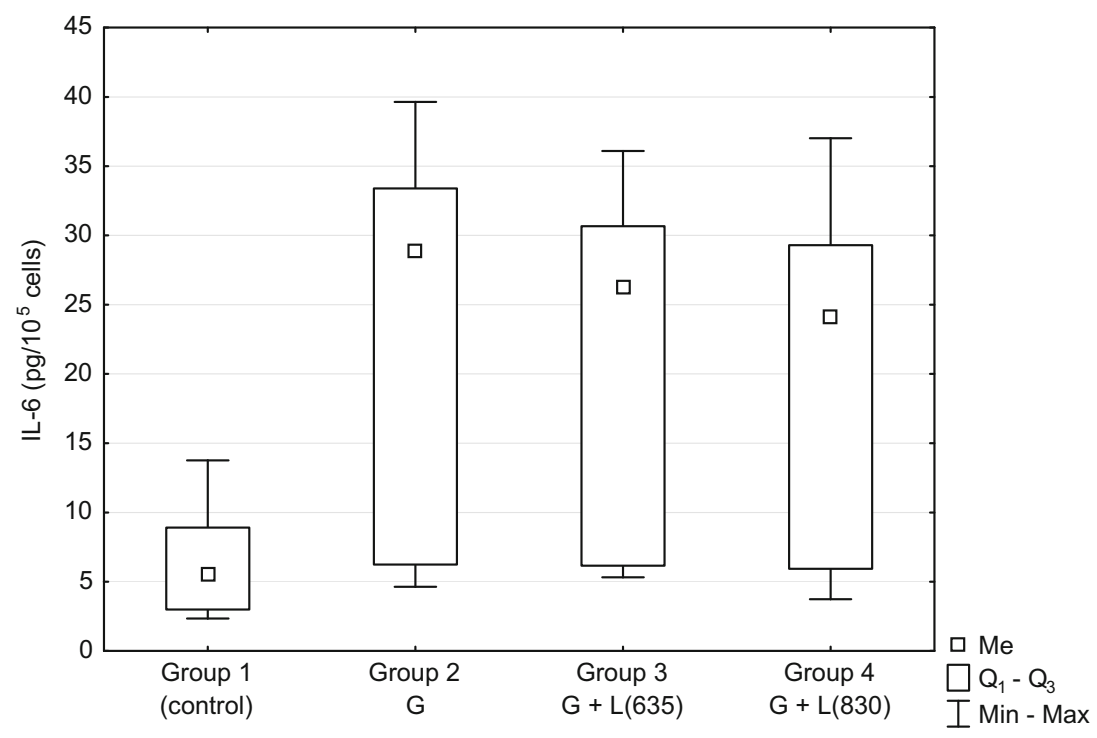

impact of high glucose concentration on the proliferation and cell viability, as reported also by other authors $[10,12]$.

In hyperglycemia, glucose is subject to auto-oxidation process and non-enzymatic glycation which leads to the production of reactive oxygen species. An increased oxidation of the cofactor NADPH to NADP+ and the reduction of NAD+ to NADH are observed [32]. These reactions disrupt a balance between oxidants and antioxidants system leading to hypoxia and synthesis of advanced glication end-product (AGE). It is the effect of cytokines, mainly TNF- $\alpha$ [26]. Hyperglycemia increases the production of free radicals in the mitochondria, particularly superoxide anion. These processes exacerbate the oxidative stress [33-35] which damages cells and induces apoptosis [36, 37]. Apoptosis may be promoted also by DNA damage $[11,38]$ and irreversible changes in cytoskeletal organization at high glucose concentration [39, 40]. IL-6 secreted during the acute phase of inflammation has varied effects on cells in diabetes [30]. Pro-inflammatory or antiinflammatory properties of IL-6 depend on the nature and function of cells and factors inducing inflammation. At high concentration, it can inhibit the production of TNF- $\alpha$ [41] which was confirmed in studies in mice [42]. The cited works have shown that the reduced level of IL-6 is associated with the impaired wound healing in diabetes.

Hyperglycemia induces the production of proinflammatory cytokines and growth factors by activating key signaling pathways associated with MAPK (mitogen-activated protein kinases), NF-KB (nuclear factor- $\mathrm{kB}$ ), and STAT3 (signal transducers and activators of transcription) [27, 31, 43, 44] depending on ROS and oxidative stress. This is related to the effect of TNF- $\alpha$ on altering the redox reaction in the mitochondrial respiratory chain $[35,45,46]$.

Although molecular mechanisms of low-power laser irradiation are still poorly understood, it is already known that the
Fig. 3 The number of HUVEC cells depending on hyperglycemia and laser irradiation of different wavelengths. G glucose in culture medium, $L(635)$ laser irradiation with wavelength of $635 \mathrm{~nm}$, L(830) laser irradiation with wavelength of $830 \mathrm{~nm}$. There was a statistically significant difference between the two experimental groups $(2,3)$ and the control group $(P=0.0207$, $P=0.0190$, respectively)

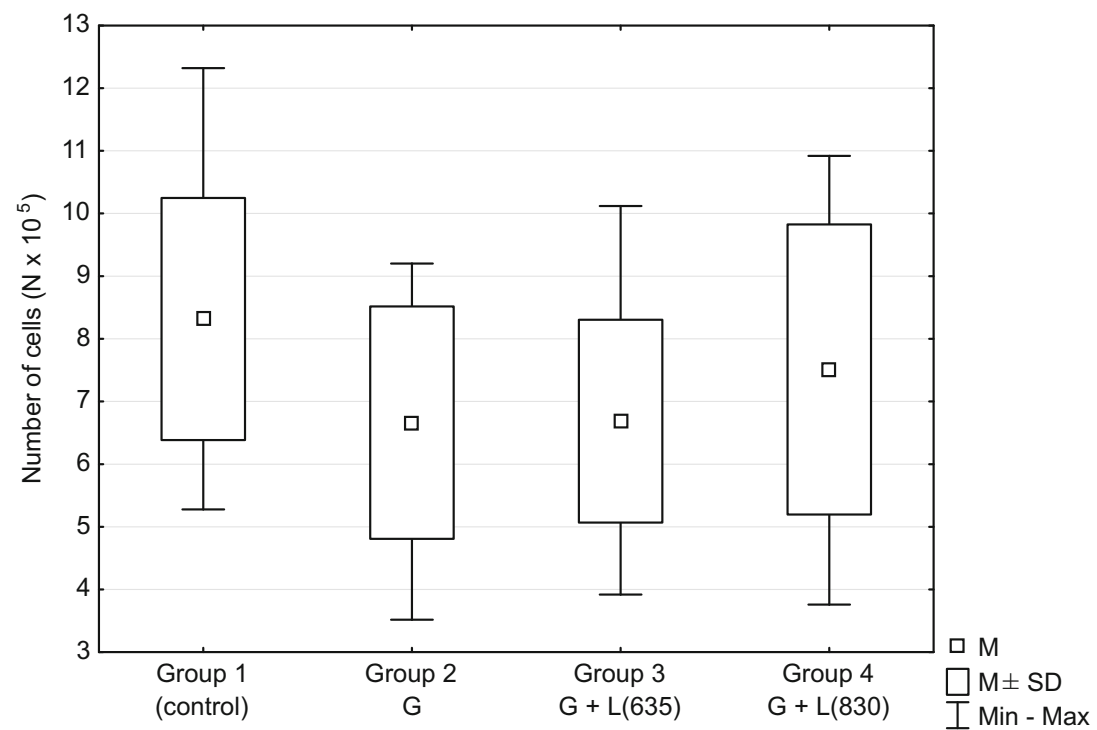


beneficial effects are associated with stimulation of cellular metabolism after energy absorption [47]. A stimulation of photoreactive proteins like cytochrome $\mathrm{C}$ occurs in the mitochondrial respiratory chain. This can increase the availability of ATP in the cells and have an influence on reactive oxygen species $[48,49]$. An improvement of the cellular energy state and normalization of cellular functions is manifested by alleviating the pain and inducing the self-healing process [50]. Kwon [16] has found that laser irradiation of osteoblasts in a diabetic model at the wavelength of $635 \mathrm{~nm}$ reduces the level of generated ROS.

Studies in animals suggest beneficial effects of LLLT in case of hyperglycemia. LLLT (wavelength of 650 and $980 \mathrm{~nm}$ ) in rats with induced diabetes has an antihyperglycemic effect without an impact on the blood morphology and biochemical profile [19]. Rabelo et al. [18] have also reported the beneficial effect of reduced inflammation in diabetic rats irradiated by $\mathrm{HeNe}$ laser at $632.8 \mathrm{~nm}$.

The effects of LLLT on various types of cells depend on irradiation parameters such as dose and wavelength. Higher doses $\left(10\right.$ or $\left.16 \mathrm{~J} / \mathrm{cm}^{2}\right)$ cause reduction of cell viability and mitochondrial activity and increase the percentage of DNA damage $[50,51]$. The wavelength is also important during irradiation of diabetic fibroblast cultures. The wavelength of $1064 \mathrm{~nm}$ gave significantly worse results in wound healing than 632.8 and $830.0 \mathrm{~nm}[51,52]$.

Our research confirms the beneficial effects of LLLT on cells cultured with high concentrations of glucose. TNF- $\alpha$ level in the group of cells cultured in medium containing high concentration of glucose decreased under the influence of laser irradiation when compared to the unirradiated group. This applies particularly to $830 \mathrm{~nm}$ (Fig. 1). $P=0.1030$ is not far from significance. This result of testing in the analysis of variance could be significantly influenced by values in group 4 (glucose in the medium, LLLT $\lambda=830 \mathrm{~nm}$ ) with an average value of TNF- $\alpha$ lower about $35 \%$ in comparison to group 2 (glucose in the medium, without irradiation). Many authors have also observed TNF- $\alpha$ reduction caused by laser irradiation $[53,54]$.

Our results show the significant increase of IL-6 induced by hyperglycemia $(P=0.0002)$; LLLT did not cause significant changes in the concentration of this cytokine in the endothelial cell culture (Fig. 2). Some authors have reported a rise in the level of IL- 6 induced by LLLT $[30,55,56]$. Houreld et al. [53] have observed only slight and statistically non-significant increase of IL-6. Some of the literature data have also reported decreased level of IL-6 under the influence of laser irradiation [56]. The result we have obtained may be in favor of beneficial effects of LLLT, since IL- 6 reducing TNF- $\alpha$ level can therefore protect cells from the damaging effect of hyperglycemia. This issue is discussed and needs further research $[8,57]$.
Data from the literature suggest that LLLT promotes the metabolic activity of cells and stimulates their proliferation $[15,58]$, in case of cells grown under hyperglycemic condition as well $[50,52,53]$. These findings are consistent with our research applying in particular $830 \mathrm{~nm}(P=0.0190$; Fig. 3). Hyperglycemic conditions significantly reduce the proliferation of HUVECs. The use of laser irradiation increases the proliferation of these cells to the level observed in the control group (non-irradiated cells in medium without glucose) (Fig. 3).

\section{Conclusion}

1. It appears that the adverse effects of hyperglycemia on vascular endothelial cells may be corrected by treatment with LLLT, especially at the wavelength of $830 \mathrm{~nm}$. It causes the reduction of TNF- $\alpha$ concentration and enhancement of cell proliferation.

2. Due to the significance of endothelial cells in the pathogenesis of diabetes and a small amount of studies evaluating the impact of LLLT on these cells under conditions of hyperglycemia, further work on this subject is warranted.

Open Access This article is distributed under the terms of the Creative Commons Attribution 4.0 International License (http:// creativecommons.org/licenses/by/4.0/), which permits unrestricted use, distribution, and reproduction in any medium, provided you give appropriate credit to the original author(s) and the source, provide a link to the Creative Commons license, and indicate if changes were made.

\section{References}

1. Brunner H, Cockcroft JR, Deanfield J et al (2005) Endothelial function and dysfunction. Part II: association with cardiovascular risk factors and diseases: a statement by the Working Group on Endothelins and Endothelial Factors of the European Society of Hypertension. J Hypertens 23:233-246

2. Werner S, Groser R (2003) Regulation of wound healing by growth factors and cytokines. Physiol Rev 83:835-870

3. Diegelmann RF, Evans MC (2004) Wound healing: an overview of acute, fibrotic and delayed healing. Front Biosci 9:283-289

4. Januszewicz W, Sznajderman M (2000) Modification of endothelial function-new method of antihypertensive treatment. Arterial Hypertens 4:195-199

5. Schalkwijk CG, Stehouwer CD (2005) Vascular complications in diabetes mellitus: the role of endothelial dysfunction. Clin Sci 109: 143-159

6. Cho M, Hunt TK, Hussain MZ (2001) Hydrogen peroxide stimulates macrophage vascular endothelial growth factor release. Am J Physiol Heart Circ Physiol 280:H2357-H2363

7. Deon D, Ahmed S, Tai K, Scaletta N, Herrero C, Lee IH, Krause A, Ivashkiv LB (2001) Cross-talk between IL-1 and IL-6 signalling pathways in rheumatoid arthritis. J Immunol 167:5395-5403 
8. Pedersen BK (2007) IL-6 signalling in exercise and disease. Biochem Soc Trans 35:1295-1297

9. Lally F, Smith E, Filer A et al (2005) A novel mechanism of neutrophil recruitment in a coculture model of the rheumatoid synovium. Arthritis Rheum 52:3460-3469

10. Kamal K, Du W, Mills I, Sumpio BE (1998) Antiproliferative effect of elevated glucose in human microvascular endothelial cells. J Cell Biochem 71:491-501

11. Lorenzi M, Montisano DF, Toledo S, Barrieux A (1986) High glucose induces DNA damage in cultured human endothelial cells. J Clin Invest 77:322-325

12. Lorenzi M, Cagliero E, Toledo S (1985) Glucose toxicity for human endothelial cells in culture. Delayed replication, disturbed cell cycle, and accelerated death. Diabetes 34:621-627

13. Carrington AL, Abbott CA, Griffiths J et al (2001) A foot care program for diabetic unilateral lower-limb amputees. Diabetes Care 24:216-221

14. Brosseau L, Robinson V, Wells G, Debie R, Gam A, Harman K, Morin M, Shea B, Tugwell P (2005) Low level laser therapy (Classes I, II and III) for treating rheumatoid arthritis. Cochrane Database Syst Rev 19:CD002049

15. Hawkins D, Abrahamse H (2007) Changes in cell viability of wounded fibroblasts following laser irradiation in broadspectrum or infrared light. Laser Chem 1:10

16. Kwon H, Lim W, Kim J, Jeon S, Kim S, Karna S, Cha H, Kim O, Choi H (2013) Effect of $635 \mathrm{~nm}$ irradiation on high glucose-boosted inflammatory responses in LPS-induced MC3T3-E1 cells. Lasers Med Sci 28:717-724

17. Esmaeelinejad M, Bayat M (2013) Effect of low-level laser therapy on the release of interleukin- 6 and basic fibroblast growth factor from cultured human skin fibroblasts in normal and high glucose mediums. J Cosmet Laser Ther 15:310-317

18. Rabelo SB, Balbin Villaverde A, Nicolau R, Salgado MC, Da Silva MM, Pacheco MTT (2006) Comparison between wound healing in induced diabetic and nondiabetic rats after low level laser therapy. Photomed Laser Surg 24:474-479

19. Cornejo-Garrido J, Becerril-Chávez F, Carlín-Vargas G, OrdoñezRodríguez JM, Abrajan-González Mdel C, de la Cruz-Ramírez R, Ordaz-Pichardo C (2014) Antihyperglycaemic effect of laser acupuncture treatment at BL20 in diabetic rats. Acupunct Med Dec 32: 486-494

20. Keszler A, Brandal G, Baumgardt S, Ge ZD, Pratt PF, Riess ML, Bienengraeber M (2014) Far red/near infrared light-induced protection against cardiac ischemia and reperfusion injury remains intactunder diabetic conditions and is independent of nitric oxide synthase. Front Physiol 5:305. doi:10.3389/fphys.2014.00305

21. Jaffe EA, Nachman RL, Becker CG, Minick CR (1973) Culture of human endothelial cells derived from umbilical veins. Identification by morphologic and immunologic criteria. J Clinical Invest 52: 2745-275

22. Gryko Ł, Gilewski M, Szymańska J, Zając A, Rość D (2012) The concept of the set to objectification of LLLT exposure. Proc. of SPIE: laser technology 2012. App Lasers 8703: 870302.

23. Basso FG, Oliveira CF, Kurachi C, Hebling J, Costa CA (2013) Biostimulatory effect of low-level laser therapy on keratinocytes in vitro. Lasers Med Sci 28:367-374

24. Liu T, Gong J, Chen Y, Jiang S (2013) Periodic vs constant high glucose in inducing pro-inflammatory cytokine expression in human coronary artery endothelial cells. Inflamm Res 62:697-701

25. Solini A, Santini E, Stephanie M, Cuccato S, Ferrannini E (2007) Effects of eudothelin-1 fibroblasts from type 2 diabetic patients: possible role in wound healing and tissue repair. Growth Factors 25:392-399

26. Acosta JB, del Barco DG, Vera DC, Savigne W, Lopez-Saura P, Nieto GG (2008) The pro-inflammatory environment in recalcitrant diabetic foot wounds. Int Wound J 5:530-539
27. Wang J, Li G, Wang Z, Zhang X, Yao L, Wang F, Liu S, Yin J, Ling EA, Wang L, Hao A (2012) High glucose-induced expression of inflammatory cytokines and reactive oxygen species in cultured astrocytes. Neuroscience 202:58-68

28. Brandner JM, Zacheja S, Houdek P, Moll I, Lobmann R (2008) Expression of matrix metalloproteinases, cytokines, and connexins in diabetic and nondiabetic human keratinocytes before and after transplantation into an ex vivo wound-healing model. Diabetes Care 31:114-120

29. Ohsugi Y (2007) Recent advances in immunopathophysiology of interleukin-6: an innovative therapeutic drug, tocilizumab (recombinant humanized anti-human interleukin- 6 receptor antibody), unveils the mysterious etiology of immune-mediated inflammatory diseases. Biol Pharm Bull 30:2001-2006

30. Hawkins D, Abrahamse H (2004) The release of interleukin-6 after low level laser therapy and the effect on migration and proliferation of human skin fibroblasts. Med Technol S Afr 18:11-15

31. Cawyer CR, Horvat D, Leonard D, Allen SR, Jones RO, Zawieja DC, Kuehl TJ, Uddin MN (2014) Hyperglycemia impairs cytotrophoblast function via stress signaling. Am J Obstet Gynecol 211:541-548

32. Tan KBC, Chow WS, Ai VHG (2002) Advanced glycation end products and endothelial dysfunction in type 2 diabetes. Diab Care 25:1055-1059

33. Hamuro M, Polan J, Natarajan M, Mohan S (2002) High glucose induced nuclear factor kappa B mediated inhibition of endothelial cell migration. Atherosclerosis 162:277-287

34. Gonzalez-Correa JA, Arrebola MM, Cansino AL et al (2006) Effects of aspirin plus alpha-tocopherol on brain slices damage after hypoxia-reoxygeneration in rats with type 1-like diabetes mellitus. Neurosci Letters 400:252-257

35. Mariappan N, Soorappan RN, Haque M, Sriramula S, Francis J (2007) TNF-alpha-induced mitochondrial oxidative stress and cardiac dysfunction: restoration by superoxide dismutase mimetic Tempol. Am J Physiol Heart Circ Physiol 293:H2726-H2737

36. Hadi HAR, Al Suwaidi J (2007) Endothelial dysfunction in diabetes mellitus. Vasc Health Risk Manag 3:853-876

37. Wu Q, Wang JH, Fennessy F, Redmond HP, Bouchier-Hayes D (1999) Taurine prevents high-glucose-induced human vascular endothelial cell apoptosis. Am J Physiol 277:C1229-C1238

38. Dinarello CA (2000) Proinflammatory cytokines. Chest 118:503508

39. Targosz-Korecka M, Brzezinka GD, Malek KE, Stepień E, Szymonski M (2013) Stiffness memory of EA.hy926 endothelial cells in response to chronic hyperglycemia. Cardiovasc Diabetol 12:96. doi:10.1186/1475-2840-12-96

40. Chen X, Feng L, Jin H (2013) Constant or fluctuating hyperglycemias increases cytomembrane stiffness of human umbilical vein endothelial cells in culture: roles of cytoskeletal rearrangement and nitric oxide synthesis. BMC Cell Biol 14:22. doi:10.1186/ 1471-2121-14-22

41. Hazel L, Kenneth A, Roebuck O (2001) Oxidant stress and endothelial cell dysfunction. Am J Physiol Cell Physiol 280:C719-C741

42. Fahey TJ 3rd, Sadaty A, Jones WG 2nd, Barber A, Smoller B, Shires GT (1991) Diabetes impairs the late inflammatory response to wound healing. J Surg Res 50:308-313

43. Kinoshita K, Tanjoh K, Noda A et al (2008) Interleukin-8 production from human umbilical vein endothelial cells during brief hyperglycemia: the effect of tumor necrotic factor-alpha. J Surg Res 144:127-131

44. Sweet IR, Gilbert M, Maloney E, Hockenbery DM, Schwartz MW, Kim F (2009) Endothelial inflammation induced by excess glucose is associated with cytosolic glucose 6-phosphate but not increased mitochondrial respiration. Diabetologia 52: 921-931 
45. Stadler J, Bentz BG, Harbrecht BG et al (1992) Tumor necrosis factor alpha inhibits hepatocyte mitochondrial respiration. Ann Surg 216:539-546

46. Suematsu N, Tsutsui H, Wen J et al (2003) Oxidative stress mediates tumor necrosis factor-alpha-induced mitochondrial DNA damage and dysfunction in cardiac myocytes. Circulation 107:1418-1423

47. Pinheiro ALB, Nascimento SC, Cieira AL et al (2002) Effects of low-level laser therapy on malignant cells: in vitro study. J Clin Laser Med Surg 20:23-26

48. Szundi I, Liao GL, Einarsdottir O (2001) Near-infrared time-resolved optical absorption studies of the reaction of fully reduced cytochrome c oxidase with dioxygen. Biochemistry 40:2332-2339

49. Gao X, Xing D (2009) Molecular mechanisms of cell proliferation induced by low power laser irradiation. J Biomed Sci 16:4. doi:10. 1186/1423-0127-16-4

50. Hawkins D, Abrahamse H (2006) The role of laser fluence in cell viability, proliferation, and membrane integrity of wounded human skin fibroblasts following helium-neon laser irradiation. Lasers Surg Med 38:74-83

51. Houreld NN, Abrahamse H (2008) Laser light influences cellular viability and proliferation in diabetic-wounded fibroblast cells in a dose- and wavelength-dependent manner. Lasers Med Sci 23:11-18
52. Houreld NN, Abrahamse H (2007) Cellular damage in diabetic wounded fibroblast cells following phototherapy at 632.8, 830, and $1064 \mathrm{~nm}$. Laser Chem 1:9

53. Houreld NN, Sekhejane PR, Abrahamse H (2010) Irradiation at 830 $\mathrm{nm}$ stimulates nitric oxide production and inhibits proinflammatory cytokines in diabetic wounded fibroblast cells. Lasers Surg Med 42:494-502

54. Yamaura M, Yao M, Yaroslavsky I, Cohen R, Smotrich M, Kochevar IE (2009) Low level light effects on inflammatory cytokine production by rheumatoid arthritis synoviocytes. Lasers Surg Med 41:282-290

55. Novoselova EG, Cherenkov DA, Glushkova OV et al (2006) Effect of low-intensity laser irradiation $(632.8 \mathrm{~nm})$ on immune cells isolated from mice. Biofizika 51:509-518

56. Sekhejane PR, Houreld NN, Abrahamse H (2011) Irradiation at 636 $\mathrm{nm}$ positively affects diabetic wounded and hypoxic cells in vitro. Photomed Laser Surg 29:521-530

57. Andersen K, Pedersen BK (2008) The role of inflammation in vascular insulin resistance with focus on IL-6. Horm Metab Res 40: 635-639

58. Góralczyk K, Szymańska J, Łukowicz M et al (2015) Effect of LLLT on endothelial cells culture. Lasers Med Sci 30:273-278 